\title{
La Personalidad Literaria de Carlos Reyles
}

Carlos Reyles, insigne novelista uruguayo, nació en Montevideo en 1868. Conoció desde niño la vida del campo, porque su padre era un rico terrateniente. Fué educado de acuerdo con los amplios medios de fortuna de que disponía su padre. Asistió sólo siete años a la escuela, donde no fué bien acogido por los muchachos menos ricos, y donde tuvo que defenderse muchas veces contra sus condiscípulos a causa de la elegancia de su traje y de sus modales refinados.

No teniendo muchos amigos entre sus compañeros de colegio, se dedicó a sus estudios, sobre todo a la lectura de los clásicos españoles. A la edad de diez años, ganó un premio en un concurso literario de la escuela. En otras materias no sobresalió, y cuando, después de siete años de asistencia, su padre le retiró de sus clases para que le acompañara en su casa de campo, el joven salió gozoso y continuó sus estudios en casa.

El padre, viudo, era un hombre vigoroso, interesado en la politica - fué varias veces diputado y senador-y ganadero apasionado. Se había consagrado al propósito de transformar la cría nacional del ganado con los mejores métodos europeos, y su estancia era un modelo de tipo inglés de la cría de animales. Ese entusiasmo se apoderó también del joven Carlos, y cuando murió su padre, él, millonario a los diez y ocho años, se casó y se entregó al cuidado de la hacienda y a estudiar y escribir.

En 1892 hizo el primero de varios viajes a Europa, donde más tarde tuvo una casa propia en París, $y$ donde visitó muchos países, enamorándose de Andalucía. Vivió casi enteramente fuera de Monte- 
video, en sus campos, en Buenos Aires durante la primera guerra mundial, y viajando por el mundo. En sus últimos años perdió mucha de su fortuna, y el gobierno le premió con una cátedra en la universidad. Murió en Montevideo, a la edad de setenta años, en 1938.

Las obras de Reyles son de dos clases: novelas y ensayos. Siendo este autor más notable por sus obras de imaginación que por las doctrinales, vamos a estudiarle más detenidamente como novelista que como ensayista.

Por la vida, su primera novela, fué publicada en 1888. Dice de ella Crispo Acosta que "fué compuesta en plena explosión romántica bajo la influencia del realismo en auge, sin ninguna de las buenas cualidades de esta escuela. El autor no podía tener, a los veinte años, el espíritu de observación y el caudal de experiencia necesarios para acometer, con éxito probable, semejante empresa..."

Según Roxlo, la aparición del libro produjo escándalo entre los literatos de su país, los cuales no veian ninguna hermosura en su técnica naturalista, que empleó el autor para atacar a la familia y a la sociedad, reaccionando, sin duda, según sus propias experiencias con sus parientes exigentes, después de la muerte de su padre.

Siguieron a esta primera obra varios cuentos, publicados en diversos lugares durante algunos años, y coleccionados algunos de los mejores en el libro titulado Las academias, del que hablaremos más tarde.

La primera novela de gran éxito de Reyles fué $B e b a$, dada a luz en 1894. El lugar de la historia es un establecimiento modelo de campo para la cría de ganado, y a base del argumento se ve la realidad de la vida campera que conocía Reyles tan a fondo. En efecto, se declàra que el protagonista, Gustavo Ribero, tiene mucha semejanża con el autor, el cual luchaba, predicaba y trabajaba igualmente para mejorar la raza de sus bestias y hacer adelantar los métodos modernos de la agricultura. $\mathrm{El}$ argumento tiende a probar que el cruce de consanguíneos, tanto entre ganado como entre seres humanos, produce monstruos; pero el tema convierte a la historia en novela de tesis, y casi destruye el interés por el hilo del argumento. Un párrafo de esta obra, citado aquí, puede dar una idea de la pasión de Ribero, y del autor, por el progreso, y sirve para 
mostrar algo del estilo y del período largo que a veces caracteriza a Reyles:

El afán de éste en ennoblecer el trabajo y elevarlo a la categoría de una ocupación racional, de mejorar sin descanso los ganados, persiguiendo un ideal de formas que no concluia de obtener, y más que nada, el tenaz empeño que lo animaba de dar al traste con lo malo, viejo y rutinario, y en su contra favorecer todo lo que fuera adelanto, progreso, rica novedad, buscando incesantemente dilatar el campo de acción de los criaderos y descubrirles horizontes llenos de promesas para que se decidieran a secundarlo en su tarea de reformador inteligente, que tanto le había de agradecer el país cuando conociera la grandeza de su obra ... eran para los Benavente delirios de los cuales se burlaban.

Beba fué aclamada por la gente uruguaya. Roxlo habla de la "esmeradísima habilidad" de Reyles en el uso del lenguaje en toda su pureza $\mathrm{y}$ en toda su música, y comenta la observación sutil de la vida nacional. Califica a la novela de naturalista, nacida de la realidad del medio, diciendo que "el naturalismo no es un estercolero, como presume don Juan Valera".

En 1896 fué publicado el primer cuento principal que había de aparecer bajo el título Las academias, que más tarde comprendió: Primitivo (1896), El extraño (1897), El sueño de rapiña (1898), Odisea de Perucho, y Mansilla (1893), Capricho de Goya (1902), y dos ensayos, Vida nueva y La vida. (Las fechas son las de la primera publicación.)

Cuatro de estos cuentos habían de servir de base y ser incorporados en sendas novelas: Primitivo - El terruño; El extraño - La raza de Cain; Mansilla - El gaucho Florido; Capricho de GoyaEl embrujo de Sevilla. En general, los cuentos muestran más unidad que las novelas de que formaron parte. Parece que el arte de crear personajes reales y verosímiles no pudo sostenerse bajo el tratamiento detallado y minucioso exigido por la forma novelesca. Sólo "el extraño", Julio Guzmán, gana unidad en la novela. Como compararemos estos cuentos más tarde, con la respectiva novela, mencionaremos ahora el tema de las otras ofrendas de Las academias: El sueño de rapiña - una historia simbólica, única en la obra de Reyles, bastante obvia y aburrida, del amor al oro; que hace que el protagonista pierda todos los otros goces de la vida. Odisea de Perucho - cuento de belleza e interés, de amor no correspondido. 
Vida nueva - un discurso que pronunció Reyles como miembro del partido liberal, al fundarse el club del mismo nombre, cuando el autor aspiraba a ser político. El discurso es hermoso y pulida su forma, pero grandilocuente, con muchas generalidades, y carece de sentido práctico. El intento patriótico de Reyles queda expresado en esta frase: "En política, como en la moral, sólo los indiferentes son criminales." $\mathrm{Y}$, por fin, La vida - descripción del ambiente de Monte Carlo y de la partida de boxeo entre Carpentier y Sullivan.

Fué con la aparición de Primitivo cuando don Juan Valera se vió obligado a tratar de poner freno, otra vez, como lo había hecho al hablar de Rubén Darío, a los escritores americanos que se habian desviado de lo castizo en el pensamiento, y cometido el crimen de preferir a los modelos franceses iconscientemente! Dice el señor Valera:

El galicismo de pensamiento es más hondo y más difícil de remediar que el de expresión.

Yo no niego que, en cada época, hay tendencias y corrientes distintas de las anteriores. Lo que niego es que deba nadie buscar la corriente o la tendencia para lanzarse en ella, premeditada y reflexivamente. Si tal hace, se expone a caer en lo amanerado, afectado y falso. Si cae en la tendencia o en la corriente, porque no lo puede evitar, porque está en medio de ella y porque es arrebatado por ella, como hombre de su época, de su siglo o de su momento histórico, todavía será lamentable que se deje arrastrar, si la corriente es mala; pero aun así, y arrebatado por ella, podrá ser el autor natural y sencillo. En el caso del sefior Reyles, que es el primero, hay la premeditación reflexiva y la voluntad de ir por dicha corriente; hay el propósito de ser sensitivo, de imitar a Suderman, a Tolstoi, a Ibsen, a D'Anninzio, a Bourget y a otros; hay, en suma, el intento de ser escritor de moda. $Y$ esto es lo que yo condeno, declarándolo aquí con dolor, porque, en mi sentir, el señor Reyles es un escritor de muchísimo talento, que no necesita para agradar ponerse de moda, sobre todo cuando la moda the parece detestable y perversa.

La nueva escuela, que el señor Reyles voluntariamente sigue, es pesimista, fatalista, materialista y atea, más o menos inconsciente.

(Cartas americanas, tomo nI.)

El señor Valera critica también el naturalismo y la falta de hermosura y, para él, de buen gusto, en representar cosas de la vida que son feas, viciosas, que no crean sentimientos nobles o actitudes serenas, 
en lo que escribe sobre El extraño. Más tarde, en su libro Incitaciones, Reyles menciona la crítica de Valera, y desde la altura de su madurez como escritor, pues ya tenía sesenta y ocho años, defiende sus motivos y su técnica, citando lo que había dicho ya, en el prólogo de Las academias:

'La novela moderna debe ser obra de arte tan exquisito que afine la sensibilidad con múltiples y variadas sensaciones $\mathrm{y}$ tan honda que dilate nuestro concepto de la vida cori visiones nuevas y claras.' Esta definición, a pesar de sus deficiencias, se acerca más a lo que es hoy la novela y al propósito de los novelistas que 'el 'mero solaz y pasatiempo' de que hablaba Valera. La novela se ha hecho obra de arte, en vez de mera narración.

Muchos creen que La raza de Cain, que apareció en 1900, es la mejor novela de Reyles. Tiene, sin duda, personajes, y no pocos, magistralmente analizados y expuestos. Al presentar "la raza de Cain" a sus lectores, Reyles crea una serie de personajes endemoniados: Julio Guzmán - "el extraño", que en el cuento de ese nombre casi engaña al lector, porque parece verdaderamente superior a sus amigos y parientes hasta pasada la mitad de la historia, aquí está presentado como un "enfermo de la voluntad", vicioso, elegante, débil, despectivo, odioso; Cacio — otro "enfermo" y débil, pero subordinado a sus rivales y a sus enemigos; $y$ que va analizándose ad nauseum; Menchaca - el marido que le consiente todo a su mujer, hasta la infidelidad y el odio, para hacerla feliz, perdiéndose en el proceso; el señor Crooker - recto, bondadoso, pero tan ocupado en sus quehaceres de negocios que no resulta una figura fuerte; Arturo Crooker - un "señorito" sin moral; Sara - una mujer sin fuerzas sino para amar; Ana - mujer que desprecia a su esposo por su misma asiduidad en tratar de complacerla; Amelia criatura fría y triste; Laura - la. novia que flirtea y engaña a los sinceros, hasta alcanzar la palabra de matrimonio de su escogido. Todos son tipos bastante reales, y ninguno puede escaparse de "la terrible sentencia que el Señor lanzó sobre Caín: no simpatizaban con las demás criaturas, perseguíalos el descontento y la incertidumbre, y de todas partes se consideraban rechazados", como dice de sus protagonistas el autor.

Escribe de esta novela Crispo Acosta: - 
La novela encierra en efecto una tesis, una lección de carácter moral: quiere incitarnos a afrontar con decisión y seriedad la única existencia posible para nosotros en las condiciones - ajenas a nuestro capricho- que la realidad impone. Se nos presenta con dicha intención el ejemplo lamentable de Julio Guzmán, Jacinto B. Cacio y el matrimonio Menchaca, aniquilados todos en el designio de eludir las limitaciones de su natural destino. ... Hay que tener en cuenta que Reyles, en esta obra, sólo estudia a la raza de Caín, y que, por eso, no es un cuadro de la humanidad completa lo que describe, sino el destino de los que, descaminados, pervierten su vida apartándola de sus fines y leyes naturales.

Por pesimista que sea la obra, de amor pervertido y de muerte, y por endiablados que sean los personajes principales, no se puede olvidar.

Durante la temporada pasada en Buenos Aires, en 1916, Reyles publicó El terruño. En esta novela incorporó el cuento de Primitivo, cambiando $\mathrm{y}$ destruyendo la unidad de la figura del campesino, que en el cuento más corto tenía mucho más fuerza y dignidad. E1 argumento de la novela tiene tres hilos: los pesares de Primitivo, burlado por su mujer y su hermanastro; una revolución típica, centrada en la figura caracteristica de Pantaleón, caudillo militar; y el tema de Tocles, el soñador idealista, convertido por su suegra a la vida útil y saludable del campo.

- El tema aparece una y otra vez, mientras se desarrolla el argumento: ;

Y Tocles, leyendo, empezaba a comprender la poesía del bregar campesino, $y$ cuánta inteligencia y noble esfuerzo demandaban aquellas tareas, tenidas en poco por él cuando no discernía bien y menos aquilataba con justeza su grande utilidad $y$ virtud educativa.

. .. el instinto vital y castizo del terruño contra la cultura exótica $y$ el racionalismo prestado del Gobierno.

El incidente más simpático es el de Goyo, que, como Don Quijote, sale "lanza en ristre" a combatir, y que logra matar, sin saberlo, debido a la obscuridad, un asno, creyendo haber matado a un enemigo político. Este ensueño se hace realidad para él, y en él vive orgulloso. La creencia de que el ensueño es más poderoso, más real, que la realidad misma, es la que Reyles reitera en sus cuentos $y$ en sus ensayos. 
Siendo la madre de Reyles andaluza, no es extraño que la ciudad de Sevilla le pareciese algo suyo, que le hablase al corazón, y que él quisiera escribir una novela ensalzando sus tres cualidades más pintorescas y para él más típicas: el canto, el baile y el toreo. A este fin, escribió El embrujo de Sevilla, que tiene por sus personajes principales un torero, de familia noble venida a menos, una bailadora gitana renombrada, y un cantor del "cante jondo", y, por añadidura, un pintor que sirve en muchos casos para expresar la filosofía del autor. El argumento de amor triangular es sólo una base para el despliegue de las escenas plásticas de la vida exaltada de Sevilla, vista en las corridas de toros, en los cafés populares y durante las procesiones y las fiestas de la Semana Santa.

Reyles defiende a "la España de pandereta" como algo muty característico y valioso:

Dios no nos da la ciencia, pero nos da la gracia, no sabemos trabajar, pero sabemos divertirnos. Otros fabrican locomotoras, nosotros, castañuelas, y como todos nos encaminamos al sepulcro, sería cosa de averiguar si es mejor hacerlo pasando las de Caín y aprisa o lenta y alegremente.

... Nosotros hemos inventado las corridas de toros, las cofradias y el arte flamenco porque no teníamos nuevos mundos que conquistar como en la época de los Reyes Católicos. Ni más ni menos, ni menos ni más. Mientras los otros países progresan y se roen el alma con el progreso, y se queman la sangre para obtener una cantidad de bienes inútiles, nosotros amasamos alegrias y fuerzas que, llegado el. momento, nos permitirán volver a ser lo que fuimos.

Recurre el autor a su teoría insistente del valor de las ilusiones:

El Don Quijote es la visión más profunda y completa que un artista haya tenido de la condición humana, de esa condición miserable y divina al mismo tiempo que nos hace vivir engendrando espejismos, fantasmas y fuegos fatuos, tras los cuales, desatentados, corremos. Pero de ahi, y eso no lo dijo Cervantes, nos viene nuestro mal y ntuestro bien: las ilusiones nos llenan de desencantos, .... y de esperanzas; nos extravian .... y nos llevan a encontrar mil ocultos caminos; nos enloquecen ....y nos hacen darle a la existencia una finalidad razonada que, sin la locura del hombre, la existencia no tendría. ... lo que le da sentido a la vida y legitima las aspiraciones superiores de la Humanidad es la locura incurable del hombre. 
Nacemos y vivimos para fabricar ilusiones y nutrirnos de ellas. Son las realidades profundas.

Reyles ataca y trata de solucionar el problema de que se preocupaban los escritores de la generación del 98 , observando:

Nosotros, para soportar las calamidades que van a sobrevenir, y rehacernos, debemos rezar de otra manera: no de rodillas ni en la iglesia, sino en pie y frente al yunque, a todos los yunques. E1 trabajo es la única plegaria que hoy llega a los pies del Altisimo. ... No es el quijotismo, sino el sanchopancismo el que nos ha llevado a la pérdida de Cuba, único florón de aquella espléndida corona colonial que nos legaron los Reyes Católicos. Acaso es un bien. Reducidos a nosotros mismos, obligados a cultivar el propio jardín, quizá sabremos hacer otra vez obra de varones, obra de machos cogotudos. ... Caballero del ideal, no desdeñes por prosaica la moderna aventura del trabajo, porque éste lleva en sí la enjundia de muchos ideales y es el más fiel servidor de la grande esperanza del hombre en que esos ideales se congregan y funden. ... Se me octurre que lo primero será conocernos, saber lo que somos y lo que pretendemos ser, y en seguida indagar en qué y en qué no concuerda nuestro instinto de dominio y nuestra ilusión vital, los grandes resortes de la vida intensa, con la grande esperanza de libertad, justicia y amor, que es, por excelencia, la ilusión vital del hombre. ... Contra la miseria, trabajo; contra la ignorancia, aprender; contra el orgullo, viajar...

Inútil es echarles la culpa de nuestra decadencia a los Austrias, a los Borbones, a los malos Gobiernos; ni pensar que la triaca del mal está en la Monarquia, la República o el socialismo. Hace siglos que todos, cada cual en to suyo, veníamos preparando la pérdida de Cuba, porque nadie, en lo suyo, hacía lo suyo.

El gaucho Florido fué escrito, aparentemente, para recordar los tiempos antiguos, cuando el gaucho fué rey de las pampas. Es una elaboración del cuento de Mansilla, y, se dice, de otro cuento corto similar. Casi no tiene argumento - se compone de una serie de incidentes típicos de aquellos días, escenas que el autor conocía perfectamente y que relata con fruición y simpatía. El diálogo en dialecto gauchesco parece bastante auténtico.

La objetividad, que es típica de esta novela, y en fin, de toda la obra de Reyles, se puede ver en su descripción plácida y serena de una escena horrorosa:

Cerca del Rancho Viejo apareció esa tarde Manduca, echado boca abajo sobre la panza y los intestinos salidos por la ancha 
puerta de una feroz puñalada que ịba del bajo vientre al tórax. Tenía el revólver en una mano, la daga en la otra. Los ex comisarios vagaban por alli, mirando al cielo. No veian. Dos tajos, hechos como por la mano delicada y experta de un cirujano, les partían las pupilas.

Como cuadro de costumbres, como muestra de escenas regionales, El gaucho Florido puede mantenerse firmemente entre los más conocidos; pero como novela, ni convence ni conmueve. Le falta unidad - le falta un fin - la acción del argumento no va a ninguna parte. Parece que después de dar algunas escenas de vida gauchesca, el autor se cansara de sus títeres, y decidiera acabar con ellos. Así, dió una muerte melodramática a Mangacha, y echó a Florido del escenario. Luego, arrepentido, levantó el telón otra vez para dar un vistazo a la escena después de algunos años. Aparecen Florido, todavía inconsolable por la muerte de su novia, y Micaela, cuyo sacrificio platónico e increíble choca al lector. No podemos menos de preguntarnos por qué Florido no cazó al asesino de su Mangacha, y dónde estuvieron sus amigos gauchos, que habrían debido ayudarle a vengarse, como en otros tiempos. El patrón resulta, entre los personajes, el único verosímil y fuerte.

Después de la muerte de Reyles en 1938, se publicaron dos libros suyos, uno de los cuales era la novela $A$ batallas de amor..., campo de pluma. Tal vez sea la "pátina de la vejez", tal vez el pulimento cuidadoso - de todos modos esta novela parece de estilo menos exaltado, más sobrio, más sencillo, más lleno de delicadas y artísticas imágenes que ninguna otra obra del mismo autor. Dice la casa editora que era "obra de la cual confesaba a sus amigos que había trabajado en ella muchos años" el autor. Al mismo tiempo, es un libro erótico malsano, del cual es difícil adivinar el propósito.

Es un estudio psicoanalítico de las mentes de los tres personajes principales - Pepe Arbiza, su ex esposa y la amiga intima de los dos-, y el amor de cada uno para los otros dos. Es también un retrato o una sátira de la alta sociedad, ociosa, rica, de intereses, imaginación y conversación viciosos, de Buenos Aires. Reyles trata de presentar en este cuadro una tabla salvadora - los cambios que dan la civilización y la vida, de las cuales la parte actual es sólo un paso hacia un futuro que acaso tenga esperanzas de ser mejor.

Pepe Arbiza es típico, según el autor, de la juventud rica de la ciudad porteña: 
Pepe recorre de prisa, como quien camina sobre brasas, una mínima parte de las cositas feas que ha hecho, y se consuela pensando que no es mejor ni peor que las gentes de su clase: tentativas para burlar a los acreedores, trampear en el juego, engañar al amigo con la mujer, manchar la pureza de tantas niñas que no sabian lo que hacian, ser duro e ingrato con las mujeres que lo amaban locamente, crueldad que le dictaba un sentimiento obscuro de venganza contra la honestidad de las mujeres en general...

Las dos mujeres de la novela representan a las de su rango y clase social :

Pertenecia al grupo muy reducido de señoras jóvenes, que formaban un mundo aparte dentro de la sociedad porteña más distinguida y refinada. La mayoría de ellas hablaban tres o cuatro lenguas, eran muy leídas, muy músicas, muy cordiales y un tanto preciosas... Lucian modelos de los célebres modistos y modistas parisinos, tenían lindas casas y recibían y agasajaban a los extranjeros y a los músicos. El cigarrillo en público, la melena un poco larga, las faldas ajustadísimas, cierto descaro y sobre todo la elegancia constituían los signos visibles que las separaban de las señoras de avant guerre...

Como la mayoría de las mujeres de su clase, juzgaba el valor de los hombres en primer término por la atracción sexual, la varonía, una cosa muy distinta de la varonil belleza; las cualidades morales, intelectuales, espirituales venian después, y no tenian específica importancia. ... Bebía y fumaba como un hombre, asistía a todos los bailes, flirteaba duro y parejo, jugaba al tenis $y$ al golf, montaba a caballo, no tenia, aparte de leer, otra ocupación que la de divertirse a raja cincha e iba a misa todos los domingos.

Como personaje secundario entra el médico, que predica la filosofía de esperanza:

... los hechos, como siempre, se han adelantado a los códigos. Por eso nos parece incoherente e incomprensible este mundo, que, entre paréntesis, va a desaparecer. No, las gentes de trabajo, los hombres de estudio, no desaparecerán; las gentes ociosas, las que han puesto los cinco sentidos en ser dichosas, ustedes, por ejemplo, sí...

'No hay duda que el mundo burgués se va a pique, pero se va a pique con todas sus construcciones, incluso el fascismo, el bolchevismo, el hitlerismo, el comunismo, y naturalmente, el ca- 
pitalismo. Indudablemente estamos mudando de conciencia, estamos atravesando una hora de transición. $\mathrm{Y}$ el paso de una época a otra no se hará $\sin$ vidrios rotos.'

La novela mantiene el interés hasta el fin -no se puede adivinar lo que va a ocurrir-, pero no conmueve. Estamos otra vez en el caso de observar unas escenas, de espiar en la mente de seres indecisos, débiles, poco gratos. El movimiento es lento, y el tema de lo saludable, física y moralmente, de labrar la tierra, la pasión constante de Reyles, está presente. La filosofía del valor de las ilusiones, sin embargo, abandona al protagonista, porque, aunque tiene su espejismo, no puede nutrirse de él. Su suicidio inesperado es interesante, pero nos deja sin cuidado.

Pasemos ahora a discutir las obras de ensayo, crítica y filosofía. Se publicó, en 1910, un tomo llamado La muerte del cisne, que contiene tres artículos basados en una elaboración de la fórmula de Nietzsche del poder y de la divinidad de la fuerza, y que predican la causa de la vida útil -iy yanqui! — que sabe lograr y democratizar sus ideales. Estos ensayos presentan también "la estrella del norte" de Reyles: el poder de la ilusión para nutrir a la raza humana.

A fines de la primera guerra mundial, Reyles produjo dos tomos, ilustrados, de encuadernación y técnica elegantísimas, Diálogos olimpicos, con la promesa de un tercero, que no hemos podido conseguir. El primer diálogo es una discusión principalmente entre Apolo y Dionisos, en la que éste representa el instinto, los placeres animales, la voluntad, el egoísmo, la energía, y aquél la disciplina, la razón, el anhelo de perfección y de Dios. El segundo libro presenta las ideas, principalmente, de Cristo y de Mammón, y el tercero había de contrastar, en discusión, las ideas de Palas y de Afrodita. La filosofía presentada en los dos tomos leídos es fácil, sin profundidad, $\mathrm{y}$ parece una racionalización $\mathrm{y}$ una justificación de los pesares del mundo o de las fuerzas del egoísmo y del interés - pesares que no se pueden cambiar, y que, por eso, debemos aceptar y aprovechar. No obstante que sea producto de las filosofias de los notables filósofos europeos; en las palabras de Reyles resulta muy débil. El autor, jugando con palabras, a fuerza de aseveraciones, muestra la conclusión que busca, sin convencer a sus lectores. Pero el estilo y el léxico le colocan entre los mejores prosistas de su tiempo. 
En 1936, ya maduro y viendo próximo sú fin, publicọ Reyles su libro Incitaciones, colección de ensayos filosóficos, que presentan varias ideas sobre la soledad, la vida y la moral, el concepto del autor de lo que debe ser el nivel estético de un escritor, la repetición del tema de la ilusión, artículos de crítica literaria sobre Marcel Proust y Paul Valéry, y un ensayo exaltado sobre "Sevilla, ciudad bruja". Menos el último, todos son de una sobriedad pulida y elegante.

Después de la muerte de Reyles, en 1938, salió Ego sum, una serie de ensayos de forma y estilo desiguales, llenos de repeticiones, citas de páginas enteras de otros de sus libros, y menos el que trata del estilo literario, de una técnica descuidada y atípica. Se pregunta el lector si deben publicarse ensayos póstumos, a menos que se sepa que el autor los hubiera destinado a la publicación sin revisarlos, o que se escojan los que represente fielmente.

Para juzgar de cualquier modo a un escritor, se debe averiguar el periodo y el movimiento dentro del cual produce sus obras, y sus propósitos. Con éstos se puede determinar si el tal autor consiguiera los resultados que pretendía. Sabemos que Reyles pertenece al grupo de los modernistas, y de sus propósitos, él mismo dice, en el prólogo a Las acadenias:

Los que pidan a las obras de imaginación mero solaz, un pasatiempo agradable, el bajo entretenimiento, que diría Goncourt, no me lean: no me propongo entretener: pretendo hacer sentir y hacer pensar por medio del libro lo que no puede pensarse sino viviendo, sufriendo $\mathrm{y}$ quemándose las cejas sobre los áridos textos de los psicólogos.

Las novelas de Reyles sí nos hacen pensar, pero esto de "hacer sentir" exige un genio de otro tipo que el de Reyles. No podemos decir que él no sea sincero. Lo es. Pero sí debemos confesar que no se entraña él mismo en sus personajes - es siempre el observador de sus mariposas, cogidas por él, y nos da cuenta de lo que ve, mirándolas donde están sujetas con alfileres a una tabla. Como dice Roxlo:

Reyles es un escritor masculino. Todo to que ve, to ve con ojos de hombre, objetivamente, $\sin$ sensiblerías... mucho a lo Maupassant. 
Reyles se las compone de tal manera que sus protagonistas, culpables o virtuosos, nos desagradan siempre. Les falta el flúido generador de la piedad o de la simpatía. No entramos nunca, de un modo completo, en el círculo en que giran sus pesadumbres, sus gozos, sus vicios, sus pasiones, sus trágicas bregas. Como sus héroes no se posesionan victoriosos de nuestra voluntad, sus héroes nos dejan libre el raciocinio y libre el corazón, permitiéndonos advertir el juego de los hilos con que el novelista mueve a sus fantoches.

Reyles presume que, lo que su pluma escribe cerebralmente, nuestros nervios lo recogerán, transformándolo en substancia cardiaca. Reyles se engaña.

En general, el lector se interesa, se entretiene, pero no siente. Hay algunos instantes, sí, cuando se entraña el lector con el personaje, pero estos momentos no se sostienen, y este es el caso más en las novelas que en los cuentos cortos.

Sin embargo, no podemos menos de ver la aguda observación de Reyles acerca de las personas y de las cosas que le circundan, y cómo se sirve de ellas:

A pesar de lo dicho no vacilo en afirmar que los personajes más reales $\mathrm{y}$ vívidos son los inventados, lo que un autor concibe en sus entrañas, nutre con su sangre y a su término da a luz como la madre al hijo. He aquí cómo esto acontece... Un tipo, un hecho, una escena cualquiera llaman la atención del novelista. Su memoria olvida presto, su inconsciente retiene $\mathrm{y}$ no sólo retiene, sino que cubre el hecho escueto de cristalizaciones como las aguas petrificantes de que nos habla Stendhal. Si sumergimos en ellas una ramita, aparece, al retirarla cierto tiempo después, toda recubierta de diamantes resplandecientes.

(Incitaciones.)

Esos "diamantes" tal vez sean lo que impide que Reyles, con el énfasis, aunque inconscientemente, en la forma y en el léxico, como buen modernista, entre en el corazón de sus personajes, presentándonoslos como hombres de carne y hueso, en vez de como títeres exagerados o estáticos, de una y otra clase o rango de la vida.

Hay en toda su obra una fuerte base de realismo. Reconocemos aciertos sutiles de psicologia y de apariencia. Todos los personajes están hechos de trozos de la realidad, pero les falta el alma, o la fuerza motriz o "emotriz" - se mueven, hablan, lloran-, pero no son. 
Por ejemplo, examinemos estos aciertos sacados de sus estudios de carácter :

Y cambiando súbitamente de pensamiento, sustituyendo, merced a una curiosa alquimia cerebral, los negros por los de color de rosa, como nos sucede a menudo, aun en los trances más dolorosos, lo que nos permite encontrar ridiculo el bonete de una señora $o_{-}$el gesto compungido de un caballero, mientras nuestros ojos lloran...

( $A$ batallas de amor.)

... le era imposible resistir a la tentación. ...E hizo este descubrimiento: que los propósitos son vanos y que sólo sabemos lo que somos y queremos al pasar de la idea al acto, o sea al realizarnos.

( $A$ batallas de amor.)

...marido y mujer permanecieron silenciosos y afligidos por un malestar idéntico al que se experimenta junto a un cadáver que nos es indiferente.

(Razo de Cain.)

Sabía que hablaba bien, y gustaba que to oyeran y admirasen sus escogidas expresiones y el vocabulario presuntuoso que solía emplear, ... No ignoraba que cuanto más conceptuosas y crespas eran sus frases, menos convencían, pero incitábalo a obrar así la extraña satisfacción de no ser de todos comprendido.

(Raza de Cain.)

... el antagonismo de sus múltiples yo...

(El extraño.)

$\mathrm{Y}$ para mostrar algo del don humorístico del autor, presentamos este trozo de diálogo que pasa entre dos seres callados y tímidos:

Primitivo colgaba el sombrero por el barbijo en el respaldar de la silla; ponia el rebenque de plata en el suelo y mateaba en silencio, contemplando distraidamente los artículos de las vidrieras y los recados, botas, pellones y cacharros suspendidos de los tirantes. Al cabo de las horas mil, decia el pulpero, cruzando la pierna y como si comentase algún diálogo interrumpido:

$-i \mathrm{Si}$, señor!

A to cual el yerno respondia en el mismo tono y haciendo et mismo movimiento:

-i Es verdad! 
$\mathrm{Y}$ eso era todo; luego volvian a descender al pozo obscuro de aquel mutismo sin pensamiento ni ensoñación.

\section{(El terruño.)}

En cuanto a la descripción de las cosas físicas, notemos el principio de $B e b a$, citando un párrafo que recuerda las frases iniciales de La barraca de Blasco Ibáñez, publicada en 1898:

El establecimiento volvía a la vida después de seis horas de tranquilo reposo. De pronto rasgó el aire el cacareo enronquecido y así como cascado de un gallo viejo; en seguida los perros, tosiendo unos y gruñendo otros, quizá para desterrar de sus pulmones el frio aspirado en toda una noche de dormir a raso, dieron en rondar los cuatro costados del edificio, olfatea por acá, olfatea por allá, buscando dónde guarecerse de la helada que caía; mugieron las vacas y balaron los-ternerillos allá, cerca de los corrales, junto a cuyos nudosos postes se arrimaba en las noches-crudas el ganado tambero, y por último rechinaron los cerrojos del portón, $y$ un hombre abrigado en un recio poncho de inviemo $y$ sobando una canción del país, atravesó el anchuroso patio, manchando por un momento el suelo con una silueta bien delineada y. vigorosa a los rayos de la luna, que en mitad del cenit dejaba caer una luz vertical, intensa y limpida, que realmente parecía pesat sobre los techos de teja del blanco caserío.

O esto, de El terruño:

Las chancletas, alineadas simétricamente, esperaban bostezando la venida de los pies; el batón de lana en invierno, de percal en verano, pero siempre del mismo corte, aguardaba triste el alma que periódicamente to habitaba, suspendido como el flácido cuerpo de un ahorcado de la perilla del lecho.

Pero al mismo tiempo que hacemos hincapié en la base de la vida real de Reyles, tenemos que admitir que algunas veces exagera y se pierde en sus anhelos hacia la belleza del léxico. Ya el doctor Arturo Torres-Rioseco ha mencionado un caso de eso, en la página 322 de str libro Novelistas contemporáneos de América, y podemos añadir lo raro de los soliloquios de Cacio en La raza de Cain, cuando todos los pormenores de su vida que tienen que ver con el asunto "bajo discusión" pasan en desfile, perfectamente alineados, lo cual no suele ocurrir cuando se piensa, sobre todo con la emoción de un Cacio. En $A$ batallas de amor, Pepe se expresa en lenguaje demasiado 
ornamentado y pulido para un hombre que está arguyendo consigo mismo. Si fuera Guzmán, si ; pero Pepe, el don Juan porteño, nada super-intelectual, dice para sí:

La idea de que un extraño se ha embriagado con los vinos de mi viña me vuelve loco rabioso. Creía que el rabiar de celos era literatura cursi, ; es realidad viva!

La suerte me ha despojado de todos esos poderes y virtudes. $\mathrm{Y}$ bien, es preciso que me acomode a mis nuevas circunstancias, a lo que soy ahora. La intransigencia y la arrogancia, después de haber pasado por ciertos aros, me quedan grandes.

Otras cosas incomprensibles son la reacción de Mangacha al ver "una piltrafa de carne sanguinolenta ... una lengua humana", cuando, con amor y admiración para Florido, como si le hubiera dado algo como un gatito, "sólo murmuró: -i Mi Floro!"; la muerte de Beba, quien, ya débil, enfermiza, se hace melodramática súbitamente, cuando siempre había sido sensata y fuerte de voluntad, al suicidarse, enroscándose del cuello hasta los pies con una cadena pesada en el muelle (lo cual es muy difícil para una persona sana, dado el peso de las cadenas), y mandando besos hacia la ciudad y hacia su querido campo al echarse al agua; y, para abreviar, los agujeros de las puertas de Buenos Aires, que permiten que Pepe vea mucho más de lo que es posible, a menos que sean enormes allá. Es imposible que Reyles no hubiera leído. "El sombrero de tres picos", y notado las limitaciones de los agujeros de las puertas de alcoba.

En un autor modernista, que se preocupa por la forma y por el estilo, es interesante observar los temas serios que le ocupan. Todavia muy joven, en el prefacio de Las academias, marcó Reyles la senda que iba a seguir:

A muchos que ignoran que el dolor es lo más soberbiamente humano que hay sobre la tierra, acaso disgustarán los asuntos que elija; acaso a otros ofendan o irriten las ideas que Las academias pueden sugerir; probable es, asimismo, que sin intento deliberado levante ampollas y reciba insultos y zarpazos. Ninguno de estos peligros se me ocultan; de sobra sé que el ir contra la corriente tiene sus quiebras, $\mathrm{y}$ ante mis ojos está la senda fácil por la cual, haciendo todeos y del brazo de la hipocresia, se sube des- 
cansadamente a las alturas ... pero, i cosas de la ardida juventud!, el camino recto, regado con la sangre generosa de los luchadores es el que me atrae. Tengo mi verdad y trataré de expresarla valientemente, porque yo, asombrado lector, humilde $\mathrm{y}$ todo, pertenezco a la gloriosa, aunque maltrecha y ensangrentada falange, que marcha a la conquista del mundo con un corazón en una mano y una espada en la otra.

Siendo un joven millonario quien lo dijo, tenemos que admirarnos de su actitud - él, que no tenía que luchar para nada. Veamos, pues, algunas de las cosas ajenas que le interesaban, además de las ya mencionadas, y dándonos cuenta, al mismo tiempo, que era interés más bien que pasión lo que él sentía.

Critica la vida de Montevideo, la existencia aburrida, malsana, vacilante, inútil de las mujeres, que no debian mostrar interés por nada intelectual; los maridos débiles, flacos, sin ambición sino para las diversiones y el bar, que cuentan con la riqueza de su familia o la de su esposa. Ataca-el esnobismo pseudo-intelectual de la alta sociedad de Buenos Aires. Alude al problema social del negro en los días de los gauchos, y de la injusticia y la corrupción de la ley de la ciudad para éstos. Descubre lo hueco e impráctico de la educación formal de su país. Presenta en detalle incidentes de una revolución, sus causas y sus tristes resultados. Describe brevemente, sin pasión, los tugurios. $\mathrm{Y}$ con amargura, reflejando sin duda sus propias experiencias, dice del patriotismo:

A mí me causa poca admiración lo que no depende de la cosa en sí. desde que he echado de ver que el egoísmo de uno se llama egoísmo y es cosa aborrecible, y al egoísmo de muchos, más feroz aún, se le llama patriotismo, y es cosa admirable.

(La raza de Cain.)

Fuerza es hablar de la técnica de un autor como Reyles, aunque muchos aspectós han saltado a la vista, en los trozos citados. Los críticos, a una, alaban la destreza y la riqueza del estilo. Dice el doctor Torres-Rioseco:

... es en la prosa un verdadero modernista. ... De España toma la lengua, una especie de casticismo sacudido por la vibración de su temperamento, un casticismo medular que en su forma externa no lo es, porque Ryles se permite el galicismo, el vocablo plebeyo y el americanismo. 
Y Roxlo:

El estilo de Reyles es una maravilla. Ese estilo es castizo, flexible, puro, sonoro, redondeado, original, sin amaneramientos $y$ muy rico en ideas...

Y Crispo Acosta habla del "lujo de su técnica artística".

Lo que más fácilmente se nota, con respecto a la técnica, es el léxico. Tiende a ser exótico, con palabras fuertes, verbos y adjetivos llenos de color y de acción. Recuerda la exuberancia de Martí, pero con más dominio y sobriedad. Se ha dicho que Reyles tiene un estilo muy masculino, y esto se puede decir de su selección de palabras. Reyles describe con exactitud lo que quiere decir, valiéndose de palabras ricas en sentido. Hay, si, cantidades de sustantivos no acompañados de adjetivos, pero, por regla general, vienen escoltados.

Como breve ejemplo de sustantivos raros, se notan: sentimentaloide, areópago, brujuleos, enjaque; verbos pintorescos: lagrimear, acibarar, quintaesenciar, madrigalizar; combinaciones: esponjosa nariz, amargor dilacerante, musical jerarquia, ensoberbecidos vástagos de la turbamulta pasiva y rebañega, enmarañada urdimbre, psíquica jugosidad, lirismo dengoso, petulante parsimonia, pudor agresivo, empecinado ahinco, parpadeo pudibundo, arrebolar la nariz, flechar los ojos, reventarle a uno el tumor lírico.

Lo barroco del estilo aparece netamente en esta cita:

Las iglesias, las virgenes violadas por el Saber, amarillean y enferman, y con ellas palidece en el mundo la estrella del reino espiritual. $\mathrm{Y}$ coincidencia peregrina: allí donde éste fué más efectivo y avasalló más tiránicamente las conciencias, no ya la clorosis, sino el acabamiento de todas las energías y la parálisis, dan seguros indicios de un lúgubre $\mathrm{e}$ inevitable fin, como si el pecado capital de desarraigar la planta humana de la tierra y cultivarla en místicas estufas, entrafiase la terrible penitencia del agostamiento, la esterilidad y la muerte.

(La muerte del cisne.)

En Ego sum, Reyles critica al escritor que esconde su falta de ideas con mal-escogidas palabras, diciendo:

En cambio, ese tipo de plumífero que recurre a los expedientes, las engañifas de baja estofa; los groseros prestigios del 
matafrón, la hojarasca, los fililíes, arrequives, perifollos, recamos y perendengues retóricos, porque su frase no es bastante bella ni perfecta para osar mostrarse desnuda, nos desvía del hilo que perseguimos; engaña y corrompe. Carece de la condición fundamental del escritor: la sinceridad. Cuanto escriba será falso; será un eco, pálido reflejo de lo que han dicho otros. Nunca nos dará una sola gota de agua de su propio manantial, porque no lo tiene...

Además de ese tipo de adorno dramático a sus ideas, Reyles sabe crear varias clases de diálogo aparentemente fieles a su ambiente, como el gauchesco que se ve en El gaucho Florido; el "sanchopancesco" de Mamagela, en El terruño, con sus adagios y dichos campestres; el de la "sociedad" de Buenos Aires, con sus abundantes palabras exóticas, como: sex appeal, boycott, pettingparty, breeches, cottage, chantage, shorts, boites de mint, affaire a trois, non c'he male (por non c'é male), le besoin dé réparer, ça se voit; y se sirve mucho de la portuguesa "testa" por "frente".

En la cita que sigue, no muy rara ni extraña, se puede ver cómo Reyles supo emplear palabras ordinarias para expresar el gradual aumento de interés de los chicos, con un "crescendo" de color en los verbos:

En los zapatos de cueros de Rusia, llenos de agujeritos y pespuntes, se detenían absortas las miradas de los humildes colegiales; subían luego, y tomaban a fijarse en la reluciente hebilla del cinturón y después, ascendiendo siempre y deleitándose en los cordones y peto blanco de la historiada blusa, se embobaban en el rostro del nuevo discípulo.

\section{(La raza de Cain.)}

Crispo Acosta critica a R̉eyles a causa de sus imágenes delicadas, en vista del vigor y machismo de su estilo. Dice:

¿Por qué ha mezclado Reyles, en algunas partes, a todo eso que le es propio como su naturaleza, el artificio que hace mirarse a la luna espejada en las aguas, como sonámbula del cielo, y dice de ella que parece una calavera de plata sobre el silencio campesino que se oye? Huelgan y chocan los adornos de puntilleo sobre la robustez de un torso varonil desnudo.

Eso no es enteramente justo. Se puede ser varonil y delicado, fuerte y tierno. Lo que sí choca son los tres o cuatro clisés, muy 
gastados, como "el naciente amor que se abría en su alma como una rosa", pero ésos se los podemos perdonar, al ver el tesoro de imágenes brillantes que nos obsequia Reyles. Las hay de todos los sentidos: oido - una voz como con notas de violoncelo; se oyen las ocarinas y los flautines de los pájaros; sin metáfora, muebles y cuadros le cantan una lontana canción; tacto - siente que tiene a la noche en los brazos, desnuda, y enjoyada; miradas pegajosas como moscas; gusto - le producía mareos el generoso mosto de la dicha; olfato - el aura que venía de las praderas abrasadas, era como el aliento cálido y podre de un enfermo; vista - a lo lejos, las finisinas muselinas de la niebla descorrianse como un telón de fondo y dejaban ver en lontananza vagas cuchillas y melancólicos ranchos, pobres nidamentas humanas, semejantes a nidos de horneros, cobijadas siempre bajo el ranaje paternal de algún frondoso ombú; mirando el encendido rubi de su puro.

Pero ¿para qué clasificarlas? Hay de todo: esta verdad, monstruo que con uñas de diamante desgarra la piel femenina de la celeste ilusión; la noche, por la puerta del oriente, se recogía las faldas y se iba del baile; los objetos se embozaban en la capa parda del creprisculo; los erectos álamos... más lejanos van entrando en la noche como una teoria de encapuchados monjes en el portal sombrio de un monasterio; adquiria la grave expresión de la gallina que está poniendo un huevo; algunos ranchos chatos que parecen tortugas durmiendo la siesta al sol; subrayando el horizonte, una hilera de álamos; la cama le espera abierta como una ostra; los muebles... limpios y puestos cada uno en su sitio, parecen sorprendidos $y$ se miran como los chiquillos que apenas se reconocen después de recibir las caricias del jabón; las rías angostas, las plazuelas... nos tratan de tú.

Hablando de ritmo y fraseo, basta repasar las citas para ver los períodos algunas veces cortos, las más veces largos, y en muchos de los cuales se ha notado un ritmo de tres: tres adjetivos, tres verbos, tres frases, tres cláusulas. No es que siempre ocurra esto, pero se nota especialmente en los ensayos, en el estilo oratorio de los discursos de Reyles, y en los Diálogos alimpicos. Aquí van otros ejemplos de esta tendencia?

Las cocinas rurales: criaderos de pulgas, posadas de perros y asilos de cosas sucias... 
Sobre todo, las honradas ollas de barro, panzudas, humildes y discretas...

(El terruño.)

Los desposeidos obtuvieron, de improviso, inagotables tesoros; los miserables, riquezas sin tasa; los tristes, alegrías infinitas...

(Diálogos olimpicos.)

Pobres pescadores, sencillos labriegos y empedernidas rameras escucharon mis palabras, abandonaron sus bienes y me siguieron.

(Diálogos olimpicos.)

Algunas veces se nota ese ritmo en combinación con una serie de ideas contrapuestas:

Por lo demás yo no proclamé la verdad, que nadie conocía ni reclamaba, sino la esperanza que todos necesitaban y pedian; no la ciencia, que desencanta, sino la fe que consuela; no el saber, que aísla y enemista, sino el amor que une las almas porque hace comprenderlo, amarlo y perdonarlo todo, ioh, dioses!...

(Diálogos olimpicos.)

Pasemos ahora al émpleo del color. El lugar importante que los colores tienen en las novelas de Reyles indica su sensibilidad a los matices. Sea que el ambiente del Uruguay parezca así, sea que el autor sólo pudo verlo de ese modo, notamos que casi toda la coloración mencionada tiene tintes grises, plomizos, mates. Las piedras preciosas figuran entre las obras de los modernistas, pero son raras en las de Reyles, menos el diamante. Hay, sí, alguna que otra mención del zafiro, del rubí, de la perla, del coral, de la turquesa, del ópalo, usados, menos el rubí, que aparece sólo en una imagen ya notada, para indicar colores de la tierra, del cielo o de la naturaleza, y, menos las dos primeras, son de color "desmayàdo", como diría Reyles.

Menos al describir a España, Reyles es enemigo de los colores brillantes. Se permite allí muchos rojos y oros, pero por lo general modifica los colores para que resulten mates. Por ejemplo, nunca habla de una luz de oro de un candil, sino de la luz mortecina, o de la luz amarillenta de una vela. Veremos, en los trozos que siguen, que rara vez hay un color sin modificación, que 
la mayor parte de ellos quedan apagados, y que los no apagados sirven, casi siempre, para dar contraste a otros menos brillantes.

Primero, algunas excepciones a lo anterior: las estrellas titilaban en el firmamento azul radioso; un nubarrón cobalto; mar azul crudo, como formado de liquidos zafiros y brillantes diamantes.

De El embrujo de Sevilla tomemos los colores que España ofrece: oros afiligranados; el añil del cielo tórnase azul rabioso; la luz viste la Giralda de sangre y fuego ... y hace del Guadalquivir un río de plata viva; abajo, el anarillo y rojo del ruedo; eñ lo alto, el azul rabioso del cielo; largas y amarillosas velas.

Pero, en su empleo 'más usual: el cuadro se patina, adquiere tonos violetas, cárdenos, vinosos, le salen ojeras; el horizonte lejano lucia esos colores desmayados y enfermos de las piedras que mueren, el coral, la turquesa; el sol... ponía en el horizonte sus finas turquesas, delicados corales y ópalos; el monte... ostentando tonos inseguros, violáceos parduzcos y grises azulados; el cerro... semejaba tno de esos pardos nubarrones; sendas... de color amarillento-parduzco; el verde subido e intenso de la cebada resaltar ba sobre el verde apagado de la alfalfa recién nacida; un tono obscuro ntate; amarillentos reflejos; el sol... se apeaba del cielo $y$ ponía en las poblaciones tenues rosas $y$ desmayados oros; los pastos amarilleaban; el verde resplandecia con el fuego de los diamantes del Brasil, y a trechos cambiaba de entonación, haciéndose más sombrio o más claro y luminoso, pasando de las tintas limpidas de la esmeralda al verde lechoso de los cardos, al verde anémico del caraguatá y de éste a los cambiantes metálicos del colibri; el verde metálico tornábase mate y sucio como la cáscara de la sandía, y la plata briñida, plata oxidada; apagadas purpuras, muertas turquesas y tintas lividas del crepuisculo; tierra negruzca; rasgaduras del desmayo azul; verde violáceo; rojo enfermizo.

Tratemos finalmente de la estética de Reyles. "El estilo es el hombre", dice Reyles, en Ego sum. Vamos, pues, a observar lo que cree él más importante para un escritor.

Subraya, siempre que habla del estilo o del léxico, la importancia de los medios expresivos, y de un conocimiento de la gramática, para expresarse debidamente. En Ego sum dice: 
Son raros los escritores que mantienen cordiales relaciones con la gramática, la retórica, e íntimo comercio con los clásicos, no para imitarlos, sería pueril, sino para sorprender los secretos de su léxico, la rịqueza del vocabulario, el arte sutil de los giros, verdaderas coyunturas de la lengua, lo que la hace flexible, flúida, ágil. Nosotros despreciamos olímpicamente gramática, retórica y clásicos; independencia y machismo criollo rechaza cuanto signifique disciplina, conocimiento formal del idioma, y de ahí las manquedades y cojeras de la expresión, el estilo indiferenciado, pobre, incoloro, aguanoso, sin nervio ni relieve ni vigor. Observe el lector que no se trata de sintaxis ortodoxa o casticismo confitura literaria; se trata de fuerza, precisión, tonicidad, vida y también de honradez literaria. No hay virtuoso de la frase $\sin$ sefiorio absoluto de la lengua...

Indicando que no seguía ciegamente las modas de Francia, que sabía pulir y seleccionar, Réyles afirma en Incitaciones:

$\therefore$ de esnobismo están infeccionados la mayoría de los escritores, unos por seguir las modas de París, otros porque son incapaces de someterse a las severas disciplinas que exige la originalidad... Comúnmente el que se pone a escribir sin haber nacido escritor, no se preocupa de encontrar la forma orgánica y viva de lo que piensa o siente, para lo cual hace falta primero conocer la ciencia oculta del leriguaje, la magia de las palabras...

¿Qué es, en suma, la calidad literaria? Que yo sepa, no se ha definido nunca, quizá porque no puede definirse... Se siente con rotunda evidencia. Yo la he sentido siempre como vibración emotiva singularísima, sutil sensibilidad intelectual, estilo, visión, densidad, sinceridad, sentido, gusto, inspiración, todas las cualidades literarias fundidas, substratadas y hechas sensibles en la tonalidad, en el timbre, que es a la materia del lenguaje lo que el oriente a la perla...

Hay muchos otros párrafos que describen lo que siente Reyles en cuanto al arte de escribir, pero la mayor parte vienen al mismo punto: - se necesita sinceridad, algo que decir, el don de la palabra, con la disciplina y el trabajo necesarios para conseguir lo anhelado. Cree en la renovación de la lengua, como buen modernista, y defiende el uso de palabras ricas, tomadas de la vida americana y de otras fuentes. El cree, también, que la función de la novela es la de penetrar "en la psicología humana y la realidad palpitante del mundo más hondamente que la historia, la psicología y las ciencias sociales". (Incitaciones.) 
Con Pirandello y Unamuno, Reyles cree en la entidad de un personaje, y dice de los suyos que "el novelista los sigue, ve lo que hacen, oye lo que dicen, pero no les impone que digan o hagan esto o lo otro... y menos tuerce su vocación. ... El personaje... es un ser inmensamente vivo, una realidad legada al culmen de la máxima realidad, que, si lograda, es la realidad artistica". (Incitaciones.)

Para concluir, debemos alabar al artista de la palabra, al creador de personajes-tipos que no se olvidan, al maestro de la imagen. Se puede decir que viste sus emociones en imágenes elegantes hasta disfrazarlas en objetividad artística, con base realista, y que to hace con vigor, fuerza y entusiasmo que despiertan en el lector igual ímpetu, igual exaltación hacia el lenguaje, aunque no sea convencido por el motivo emotivo del autor.

En Ego sum, criticando a los no-escritores, Reyles les aconseja que dejen de escribir, porque no alcanzarán a producir nada. Las palabras siguientes expresan tan hondamente los sentimientos de Carlos Reyles que sabemos que él sí supo realizar los goces supremos de los que nos habla aquí, que para él, eran la vida:

Rompa la pluma y haga otra cosa. Nunca podrá remontar el vuelo; nunca su verbo paralítico será el cóndor, que haciendo majestuosas espirales asciende a las alturas heladas y puras; nunca se lanzará de allá arriba sobre su presa, fulgurante y veloz como el rayo; por ponderadas que sean sus facultades querrá cantar una romanza y en vez de notas, emitirá vagidos; no conocerá jamás el goce supremo de escribir la maravillosa urdimbre de las palabras, ni sabrá que son mundos mágicos llenos de imágenes, símbolos y misterios, habitados por traviesos geniecillos y dioses taumaturgos de infinitos poderes.

Martha Allen, Mills College, Oakland, California. 


\section{B I B L IOGRAFIA}

Beba, ed. Ercilla, Santiago de Chile, 1936.

El gaucho Florido, ed. Espasa Calpe Argentina, 1939.

La raza de Cain, ed. Ercilla, 1937.

El terruño, ed. Ercilla, 1936.

A batallas de amor... campo de pluma, ed. Sopena, Buenos Aires, 1939.

El embrujo de Sevilla, ed. Ercilla, 1937.

Las academias, ed. C. García \& Cía., Montevideo, 1940.

La muerte del cisne, Ediciones Literarias, Garnier, París, 1910.

Diálogos olimpicos, Imp. Casa Peuser, Buenos Aires, 1918-1919.

Incitaciones, ed. Ercilla, 1936.

Ego stm, ed. Sopena, 1939.

C $R$ I T I C A

Cartas americanas, de Juan Valera, tomos m y iv (xLIII y xutv de sus obras completas), ed. Imp. Alemana, Madrid, 1916.

Historia crítica de la literatura urtuguaya, de Carlos Roxlo, tomo Iv, ed. Barreiro y Ramos, Montevideo, 1912-1916.

Carlos Reyles, de Osvaldo Crispo Acosta, ed. Barreiro \& Cía., Montevideo, 1918.

Novelistas contemporáneos de América, de Arturo Torres-Rioseco, ed. Nascimento, Santiago de Chile, 1940. 
